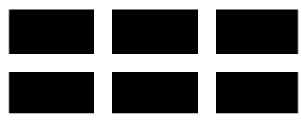

THE WILLIAM DAVIDSON INSTITUTE AT THE UNIVERSITY OF MICHIGAN BUSINESS SCHOOL

Intra-industry Trade of Transition Countries: Trends and Determinants

\author{
By: Yener Kandogan
}

William Davidson Working Paper Number 566

May 2003 
Title: Intra-industry Trade of Transition Countries: Trends and Determinants

Author: Yener Kandogan

Affiliation: University of Michigan-Flint

Address: School of Management

University of Michigan-Flint

303 E. Kearsley

Flint, MI 48502

Email: yener@umich.edu

Abbrev. Title: IIT trends and determinants 


\title{
Intra-industry Trade of Transition Countries: Trends and Determinants
}

\begin{abstract}
:
This paper analyzes trends in different components of trade of transition countries. To explain the cross-country differences, the paper points out the important distinction between the determinants of inter-industry trade and intra-industry trade (IIT), and horizontal and vertical IIT. Using varieties of gravity models, it is shown that variables from Increasing Returns Trade Theory, such as scale economies, similarity of income levels, and number of varieties produced play important roles in IIT, especially in horizontal IIT, whereas factors such as comparative advantage, dissimilarity in income levels, and having more developed trade partners of Heckscher-Ohlin Trade Theory are crucial in determining inter-industry trade and vertical IIT to a lesser degree.
\end{abstract}

JEL Classification: F14, P2

Keywords: Vertical and horizontal intra-industry trade, transition countries, gravity models 


\section{Introduction}

The empirical success of gravity equation in explaining trade volumes is indisputable. However, whether this success is evidence in support of which of the two main competing trade theories is still not clear. Although several authors in search for a theoretical basis came up with models that are based on Increasing Returns Trade Theory (Anderson, 1979; Bergstrand, 1985, 1989, 1990), Deardorff (1995) characterized gravity equation with two cases of Heckscher-Ohlin Theory. To resolve this issue, Evenett and Keller (2002) examined the H$\mathrm{O}$ and the IR theories together to conclude that both theories explain different components of trade volume, and thus found theoretical support for both in gravity models.

This paper intends to contribute to this discussion empirically. Fast evolving transition countries' trade with their developed and developing partners in 1990s are analyzed. Given the heterogeneity across transition countries, this geographical area provides a perfect setting to examine the role of these competing theories in different components of trade. ${ }^{1}$

Gravity models are typically used to explain total trade volume. Since parts of this total trade are explained by different trade theories, there is a need to decompose total trade into its parts and analyze each component separately. Section 2 further elaborates on the need to decompose and then decomposes total trade into its inter- and intra-industry parts, as well as vertical and horizontal parts of intra-industry trade.

In Section 3, regressions derived from different forms of gravity models are run separately on each trade component to examine the role of competing trade theories. It is found that elements of $\mathrm{H}-\mathrm{O}$ theory such as large factor endowment differences, measured by dissimilarity in income levels, and relative revealed comparative advantage, as well as elements of IR theory like economies of scale, and number of varieties produced help explaining inter-industry trade 
and intra-industry trade (IIT), respectively. Both $\mathrm{H}-\mathrm{O}$ theory and IR theory factors play a smaller role in vertical IIT, as it stems from relative factor intensity differences within an industry. This finding supports Greenaway and Torstensson's (2000) empirical analysis of OECD trade. Section 4 concludes the paper with comparison of results with recent research on other regions.

\section{Decomposition of total trade}

Inter-industry trade is a consequence of different factor endowments and the resulting specialization predicted by Heckscher-Ohlin trade models. This trade theory is believed to explain mainly the trade between developed and developing countries. On the other hand, intra-industry trade has been significant between developed countries, resulting in a series of research to become the Increasing Returns Trade Theory built around the Krugman (1979) model. $^{2}$

Intra-industry trade is composed of two significantly different parts. Horizontal IIT occurs when similar products are simultaneously exported and imported mainly due to product differentiation. Vertical IIT is defined by Grubel and Lloyd (1975) as the simultaneous export and import of goods in the same industry but at different stages of production. This results from vertical disintegration of production due to varying factor intensities within an industry.

Given the theoretical differences explaining each component of trade, there is a clear need to decompose total trade into its parts. In fact, Greenaway et al. (1995) demonstrate that a failure to separate horizontal and vertical IIT can negatively impact the interpretation of

empirical results. ${ }^{3}$ Widely cited use of decomposing trade into its intra- and inter-industry components is adjustment cost estimation, where IIT type changes in trade as a result of 
liberalization are expected to cause lower adjustment costs. An extension of this reasoning is used in Kandogan (2003) for decomposing IIT into its horizontal and vertical parts, given that the latter also stems from factor intensity differences, although these are within-industry differences. Broll and Gilroy (1988) give another reason for decomposing trade by examining the relation between intra-industry trade and technology diffusion.

A frequently used method to decompose IIT into its parts is based on ratio of unit values of exports. This technique has been criticized by the randomness in the choice of threshold ratio, which is used to determine whether IIT in an industry is vertical or horizontal. Therefore, a newer method proposed in Kandogan (2003) is used in this study. This method is based on the definitions for each part of IIT provided earlier. It uses values of exports and imports at two different levels of aggregation without any need for data on quantity of exports and imports. The higher level of aggregation defines industries, and the lower level of aggregation defines different products in each industry. Trade in products of an industry are aggregated to find the trade in that industry as follows:

$$
X_{i}=\sum_{p} X_{i p} \quad M_{i}=\sum_{p} M_{i p}
$$

Using trade data at higher level of aggregation, the total amount of IIT in each industry is computed by finding the amount of exports matched by imports, following Grubel-Lloyd (1975). Then, the amount of matched trade in each product of an industry is computed using data at lower level aggregation. This gives the trade of similar products, i.e. horizontal IIT. The rest of the IIT in this industry is the trade of different products or products at different 
stages of production within that industry, i.e. vertical IIT. Unmatched part of the total trade $(T T)$ in the industry is inter-industry trade (INT):

$T T_{i}=\sum_{p} X_{i p}+M_{i p}=X_{i}+M_{i}$

$I I T_{i}=T T_{i}-\left|X_{i}-M_{i}\right|$

$I N T_{i}=T T_{i}-I I T_{i}$

$H I I T_{i}=\sum_{p} X_{i p}+M_{i p}-\left|X_{i p}-M_{i p}\right|$

$\operatorname{VIIT}_{i}=I I T_{i}-H I I T_{i}$

Data on trade is obtained from International Trade Centre UNCTAD/WTO that uses SITC Revision 3. Trade of 10 Central and East European countries (CEEC), and 12 Former Soviet Union (FSU) countries with 18 developed and 10 developing trade partners are analyzed. Partner countries are chosen to represent the most important trade partners for the transition countries. Data covers the period of 1992-1999, which immediately follows the trade liberalizing Europe Agreements between the CEEC and the EU. FSU countries are considered separately since their trade liberalization has been regional, if at all, among themselves under Commonwealth of Independent States (CIS) customs union. ${ }^{4}$ Table 1 provides the list of transition countries analyzed, and their trade partners.

Figure 1 plots the exports and imports of transition countries. It is observed that major EU countries dominate the CEEC trade, as well as EU countries in close proximity to CEEC such 
as Austria. The role of economic size, proximity, and liberalization agreements is clear. Although the same major EU countries are important players in CIS trade, the US and Japan, as well as regional powers surrounding CIS countries, such as Finland, Turkey and China have important places in CIS trade. Given its relative small size, Turkey's trade with Central Asian countries is striking. ${ }^{5}$ Common language might be an important determinant.

When decomposing this total trade into its parts, the 4-digit level is used to define products, and the 2-digit level for industries. Figure 2 gives the trends in inter-industry, horizontal and vertical IIT of transition countries over the period analyzed. It is seen that trade volume of transition countries soared in the 1990s, with particularly strong increases in vertical and horizontal IIT. Djankov and Hoekman (1996) also find high growth rates in vertical IIT of CEEC with the EU in their early analysis, and reason it with high inflows of foreign direct investment. While five Visegrad countries dominate the charts of CEEC, Ukraine, Kazakhstan and Belarus appear to be the most important countries in CIS charts. It is interesting that while Russia's inter-industry trade with its partners is the highest among all transition countries, it is practically absent in both horizontal and vertical IIT charts.

The aggregation of 2-digit results into 1-digit categories produce sector level results such as those in Figure 3. This figure depicts the volumes of different types of trade in 9 sectors, summed over all transition countries. It is seen that more than half of trade in the manufacturing and the machinery sectors are IIT, where the share of vertical IIT is almost equal to that of horizontal IIT. $^{6}$ Specialization is particularly strong in fuels, crude materials, and animal and vegetable oils sectors, where most of the trade is of inter-industry type. This explains the earlier observation on Russia's trade. Overall, this figure tells that IIT, especially HIIT, is more common in sectors where there is significant production differentiation such as 
manufacturing. It is insignificant, in sectors with standardized products such as natural resources, where most trade is inter-industry.

The choice of partner also affects the composition of trade, as seen in Figure 4. A big percentage of trade with developed countries is IIT, with bigger share in horizontal IIT. ${ }^{7}$ Intraindustry trade takes only a small portion of trade with developing countries, where the majority of IIT is vertical. This figure points out the role of different income levels, and relative factor endowments in explaining the volume of different components of trade. As countries become similar in factor endowments, and thus income levels, inter-industry trade loses its dominance, and horizontal IIT becomes more important.

\section{Gravity models}

In this section, determinants of total trade, and each component of total trade are analyzed using a variety of gravity models. Regression (1) in Table 2 is the simplest form of gravity model, where total trade is regressed against GDP of both transition and partner country, and the distance between the capitals of the two countries. ${ }^{8}$ Countries are expected to trade more if their economic size is larger, and the distance in between is smaller. All gravity models in this study strongly support this expectation.

Modified versions of such models can be obtained with the addition of more variables: Liberalization, common language, common border, and foreign direct investment are all tradepromoting factors. Their effects are captured by dummy variables in regression (2). All expect common border are shown to have significant positive effects on total trade volume.

Further additions to the model come from specific trade models: The Heckscher-Ohlin Trade Theory explains trade by differences in factor intensities. A number of different 
variables are used in regressions (3)-(5) to capture this: dissimilarity in per capita GDP, dummy variable for developed partner, and relative revealed comparative advantage (RRCA). All except RRCA seem to have significantly positive effects on the total trade volume. Increasing Returns Trade Theory implies higher trade volumes, when there are scale economies, income levels are similar, and there is product differentiation. Regressions (6) and (7) support this theory using number of products that transition countries import and export to proxy for product differentiation. ${ }^{9}$ Economies of scale is captured by GDPs of both the transition countries and their partners. Since it is also part of the simplest form of the gravity equation, its significance cannot yet be used in support of this theory in gravity models explaining total trade.

Note that neither theory perfectly explains total trade by itself: Dissimilarity of income appears to increase total trade volume, which is supported by the H-O theory but it is contradictory to the IR theory. Similarly, relative revealed comparative advantage seems to decrease the total trade volume, against the $\mathrm{H}-\mathrm{O}$ theory's predictions. Using different combinations of variables in regressions (8) and (9) does not affect the sign or the significance of the coefficients. A possible explanation for this is that each theory explains different components of trade, and gravity models considered so far tried to explain the total trade.

Table 3 gives the results of gravity models where different components of total trade are treated separately. In these regressions, explanatory variables are regressed against each component of trade with the addition of dummy variables for horizontal and vertical IIT, and interaction of these dummy variables with explanatory variables. These models help us analyze whether the effects of explanatory variables are different for each component of trade. 
Regression (1) shows that distance is a more important trade dampening factor for IIT, especially for vertical IIT. ${ }^{10}$ This result is expected since vertical IIT requires a product to travel the distance between the countries twice at different stages of production. It is also seen that the GDP of both transition and partner country significantly increases horizontal IIT, with insignificant increases in vertical IIT. This should not be considered as a strong evidence for the effect of scale economies on IIT, as it loses its significance in later regressions. ${ }^{11}$

In regression (2), significantly more positive effect of liberalization on IIT relative to interindustry trade is noteworthy. Liberalization has a positive effect, especially on horizontal IIT. The effects of common language, and FDI are significantly positive on only inter-industry trade, whereas FDI significantly decreases the volume of horizontal IIT. The purpose of FDI in transition countries seems more to exploit differences in comparative advantage than easier access to local markets. Dissimilarity of per capita GDP increases inter-industry trade, and decreases both IIT, with a smaller decrease in its vertical part. This result can be construed as evidence for both $\mathrm{H}-\mathrm{O}$ and IR theories.

Regressions (3)-(5) analyze the effects of other IR and H-O theory variables. It is observed that IR variables, such as the number of products exported or imported, have more positive impacts on IIT components, especially horizontal IIT. Similarly, the H-O variable RRCA has a more negative impact on IIT, in smaller magnitudes for vertical IIT. Dummy variable for developed partner has a positive impact on all components of trade, with an additional impact on IIT, especially its vertical part.

So far, the evidence for both theories is not conclusive. The varying effects of product differentiation, comparative advantage, and difference in income on each component of trade are encouraging and in support of both theories. However, there is still a positive effect of the 
number of products, and a negative effect of RRCA on inter-industry trade, which is against the expectations of IR and $\mathrm{H}-\mathrm{O}$ theories, respectively.

These problems are eliminated when IR and H-O variables are regressed against shares of each component of trade rather than the volume of each in Table 4. In these regressions, economies of scale, measured by GDP of both countries, has a negative effect on the share of inter-industry trade, and positive effects on shares of both IIT, especially horizontal IIT. This accompanied with negative effect of number of products on share of inter-industry trade, and positive impact on shares of both IIT with much bigger impact on horizontal IIT can be viewed as evidence in support of IR theory in explaining IIT. Furthermore, it is also observed that RRCA now has a positive effect on the share of inter-industry trade and a negative impact on the shares of IIT components, with slightly smaller impact on vertical IIT. ${ }^{12}$ This presents an evidence supporting the H-O theory's in explaining inter-industry trade. Dissimilarity of income levels increases the share of inter-industry trade, and decreases that of both parts of IIT, in support of both $\mathrm{H}-\mathrm{O}$ and IR theories, respectively. Lastly, in these regressions, the effect of a common border becomes significant on vertical IIT, and the effect of FDI on IIT, especially vertical IIT, is strengthened.

\section{Conclusions}

This paper analyzed the determinants of components of trade using the trade between 22 transition countries with 28 developed and developing countries over 1992-1999. It showed that the inter-industry component of trade is explained by the Heckscher-Ohlin Trade Theory, and the intra-industry trade components are explained by the Increasing Returns Trade Theory with some impact of the H-O Theory on its vertical part. Since gravity models try to explain 
total trade, composed of these components, both of the competing trade theories are behind the success of the gravity models.

This paper used a more recent technique to decompose IIT into its vertical and horizontal parts, to obtain results that are in conjunction with recent studies on other regions: Ekanayake (2001) examines Mexican IIT without decomposing it into its vertical and horizontal parts. He finds that IIT is positively correlated with income level, country size, trade intensity, trade partners, common border, and language, and liberalization agreements; and negatively correlated with inequality in income and country size, distance, and trade imbalance. Kim and Choi (2001) decompose Korean IIT into its parts using the ratio of export unit values. They conclude that vertical IIT is explained by differences in per capita income and FDI, whereas horizontal IIT is primarily determined by product differentiation, per capita income level.

Decomposing eight CEEC's IIT using the ratio method, Aturupane et al (1999) find that the total IIT is determined primarily by product differentiation, scale economies, and FDI. Horizontal IIT positively related to FDI and product differentiation but negatively to scale and labor intensity. This paper also points out the role of income similarity to explain total IIT, and the effect of common borders on vertical IIT. Contrary to Aturupane (1999), stronger effect of FDI is found on vertical IIT. 


\section{References}

Anderson, James E. “A Theoretical Foundation for the Gravity Equation” American Economic Review, 69, 106-116, 1979.

Aturupane, Chonira, et al. "Horizontal and Vertical Intra-industry Trade between Eastern Europe and the European Union” Weltwirtschaftliches Archiv, 135(1), 62-81, 1999.

Bergstrand, Jeffrey H. "The Gravity Equation in International Trade: Some Microeconomic Foundations and Empirical Evidence" Review of Economics and Statistics, 67, 474-481, 1985.

Bergstrand, Jeffrey H. "The Generalized Gravity Equation, Monopolistic Competition, and the Factor-Proportions Theory in International Trade" Review of Economics and Statistics, 71,143-53, 1989.

Bergstrand, Jeffrey H. "The Heckscher-Ohlin-Samuelson Model, the Linden Hypothesis and the Determinants of Bilateral Intra-Industry Trade” Economic Journal, 100, 1216-29, 1990.

Bhattacharyya, Ranajoy. "Vertical and Horizontal Intra Industry Trade in some Asian and Latin American Less Developed Countries” Journal of Economic Integration, 17(2), 273-96, 2002.

Broll, Udo, and Gilroy, Bernhard M. "Intra-industry Trade and Differences in Technology" Scottish Journal of Political Economy, 35(4), 399-403, 1988.

Clark, Don P., and Stanley, Denise L. "Determinants of Intra-industry Trade between Developing Countries and the United States" Journal of Economic Development, 24(2), 79-94, 1999. 
Clark, Don P. "Recent Evidence on Determinants of Intra-industry Trade" Weltwirtschaftliches Archiv, 129(3), 332-44, 1993.

Davis, Donald R. "Intra-industry Trade: A Heckscher-Ohlin Ricardo Approach" Journal of International Economics, 39(3-4), 201-26, 1995.

Deardorff, Alan V. "Determinants of Bilateral Trade: Does Gravity Model Work in a Neoclassical World?” NBER Working Paper 5377, 1995.

Djankov, Simeon, and Hoekman, Bernard. "Intra-industry Trade, Foreign Direct Investment and Reorientation of East European Exports” CEPR Discussion Paper 1377, 1996.

Durkin, John T., and Krygier Markus. "Differences in GDP per Capita and the Share of Intraindustry Trade: The role of Vertically Differentiated Trade" Review of International Economics, 8(4), 760-74, 2000.

Durkin, John T., and Krygier Markus. "Comparative Advantage and the Pattern of Trade within Industries” Review of International Economics, 6(2), 292-306, 1998.

Ekanayake, Ekanayake M. "Determinants of Intra-industry Trade: The case of Mexico" International Trade Journal, 15(1), 89-112, 2001.

Evenett, Simon J., and Keller, Wolfgang. "On Theories Explaining the Success of the Gravity Equation” Journal of Political Economy, 110(2), 281-316, 2002.

Gonel, Feride D. "How Important is Intra-industry Trade between Turkey and its Trading Partners? A Comparison between the European Union and Central Asia Turkic Republics" Russian and East European Finance and Trade, 37(4), 61-76, 2001.

Greenaway, David, and Torstensson, Johan. "Economic Geography, Comparative Advantage and Trade within Industries: Evidence from the OECD" Journal of Economic Integration, 15 (2), 260-80, 2000. 
Greenaway, David, et al. "Vertical and Horizontal Intra-industry Trade: A Cross Country Analysis for the United Kingdom” Economic Journal, 105(433), 1505-18, 1995.

Grubel, Herbert G., and Lloyd, Peter J. Intra-industry Trade: The Theory and Measurement of International Trade in Differentiated Products, London, 1975.

Kandogan, Yener. "Reconsidering the Adjustment Costs of the Europe Agreements" Applied Economics Letters, forthcoming in 2003.

Kim, Chiho, and Choi, Yo C. "Intra-industry Trade of Korea: Its Trends and Determinants" Bank of Korea Economic Papers, 4(1), 126-59, 2001.

Krugman, Paul R. "Increasing Returns, Monopolistic Competition, and International Trade" Journal of International Economics, 9, 469-79, 1979.

Torstensson, Johan. “Can Factor Proportions Explain Vertical Intra-industry Trade?” Applied Economic Letters, 3(5), 307-9, 1996. 
Transition Countries

\begin{tabular}{ll}
\hline Central and East European (CEEC) & Former Soviet Union (FSU) \\
\hline Bulgaria (BG) & Armenia (AM) \\
Czech Republic (CZ) & Azerbaijan (AZ) \\
Estonia (EE) & Belarus (BY) \\
Hungary (HU) & Georgia (GE) \\
Latvia (LV) & Kazakhstan (KZ) \\
Lithuania (LT) & Kyrgyzstan (KG) \\
Poland (PL) & Moldova (MD) \\
Romania (RO) & Russia (RU) \\
Slovakia (SK) & Tajikistan (TJ) \\
Slovenia (SI) & Turkmenistan (TM) \\
& Ukraine (UA) \\
& Uzbekistan (UZ)
\end{tabular}

Trade partners

\begin{tabular}{ll}
\hline Developed & Developing \\
\hline Austria (AT) & Brazil (BR) \\
Belgium-Luxembourg (BE) & China (CN) \\
Canada (CA) & Egypt (EG) \\
Denmark (DK) & Greece (GR) \\
Finland (FI) & Indonesia (ID) \\
France (FR) & Korea (KR) \\
Germany (DE) & Philippines (PH) \\
Hong Kong (HK) & Portugal (PT) \\
Italy (IT) & Thailand (TH) \\
Japan (JP) & Turkey (TR) \\
Netherlands (NL) & \\
Norway (NO) & \\
Singapore (SG) & \\
Spain (ES) & \\
Sweden (SE) & \\
Switzerland (CH) & \\
United Kingdom (GB) & \\
United States (US) & \\
\hline
\end{tabular}

Table 1. List of transition countries and their trade partners

Notes: Estonia, Latvia and Lithuania as considered outside the FSU because of the similarity in their relations with the EU to other CEEC.

Partner countries are grouped into developed and developing based on their average GDP per capita PPP during the period analyzed, where the cut off is set at $\$ 15,000$. 
William Davidson Working Paper 566

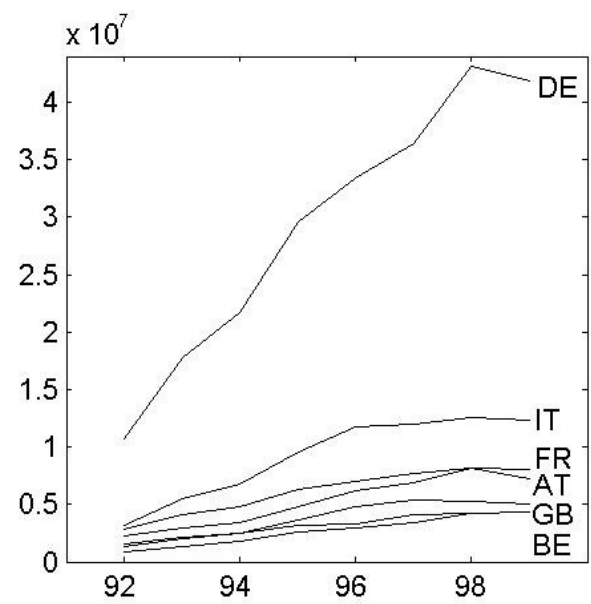

(a) CEEC Imports

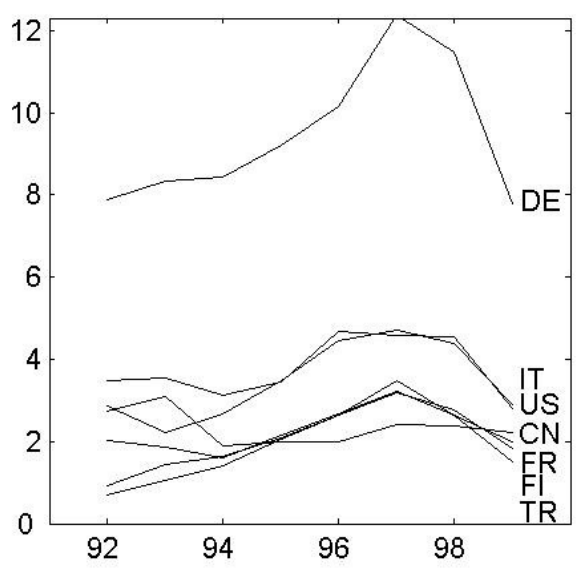

(c) CIS Imports

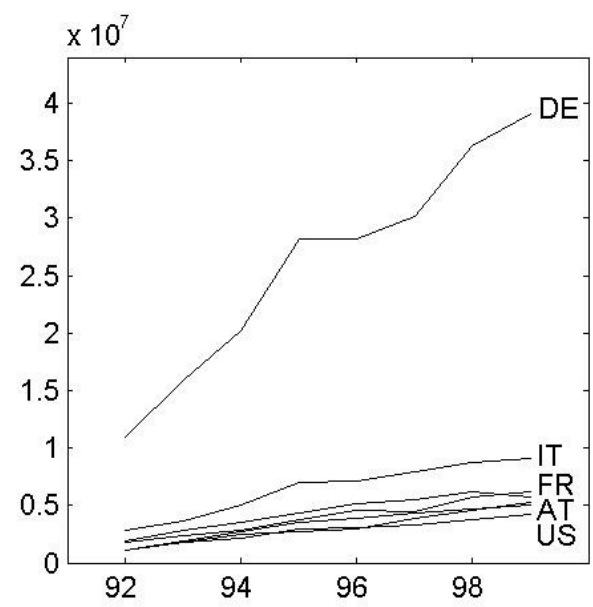

(b) CEEC Exports

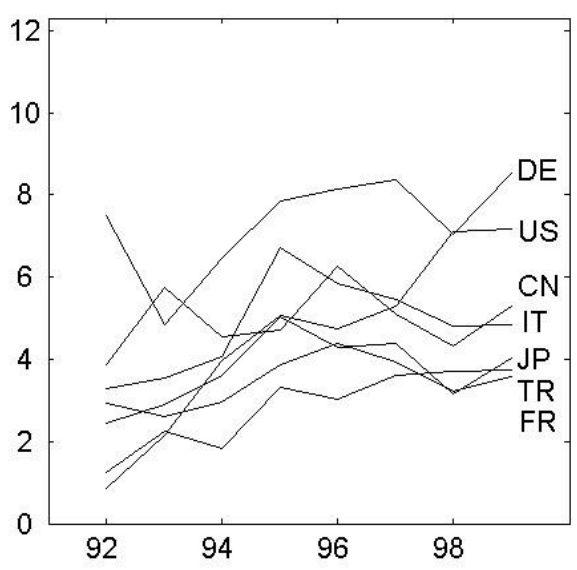

(d) CIS Exports

Figure 1. Transition countries trade with their partners 
William Davidson Working Paper 566

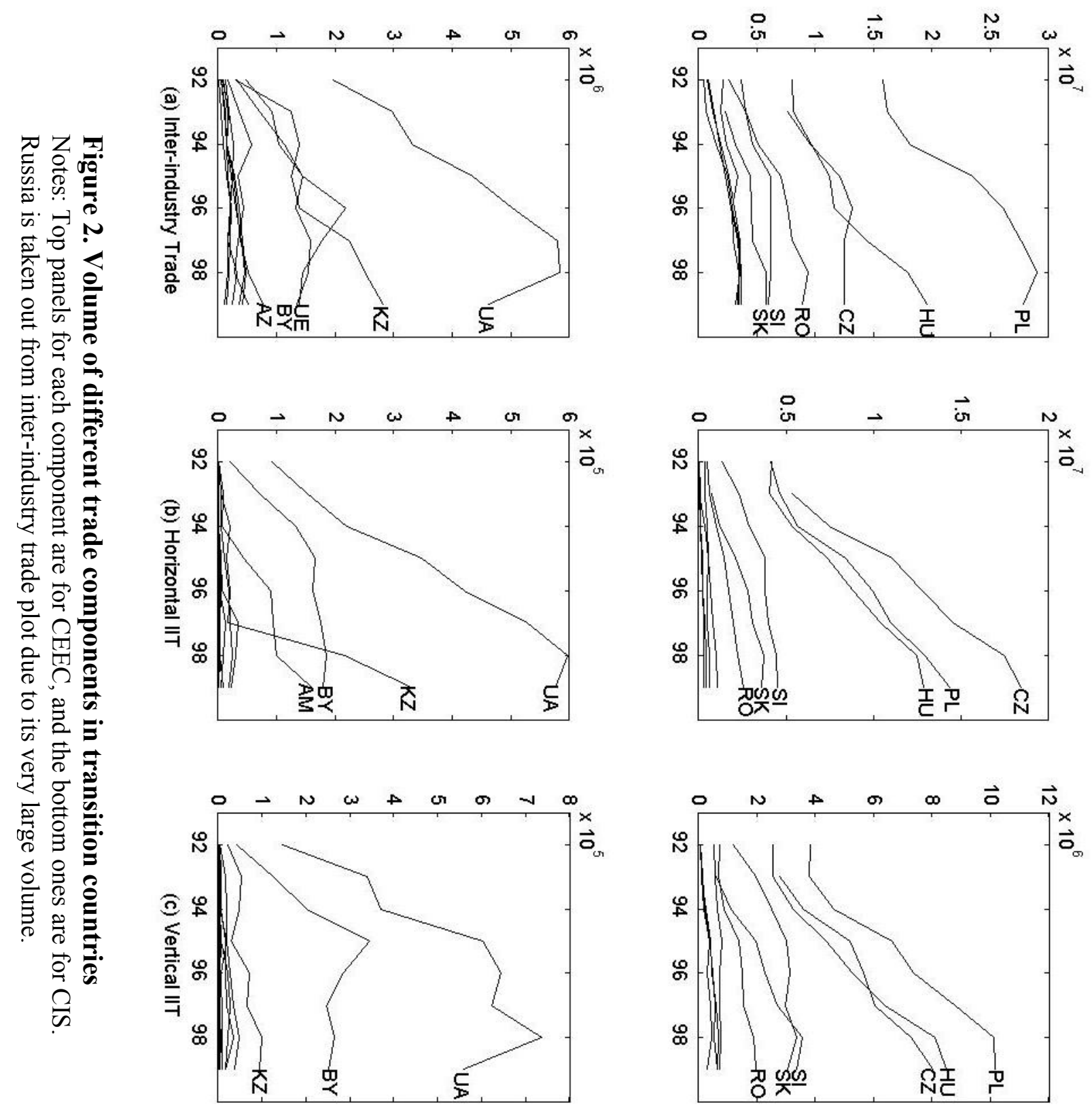


William Davidson Working Paper 566

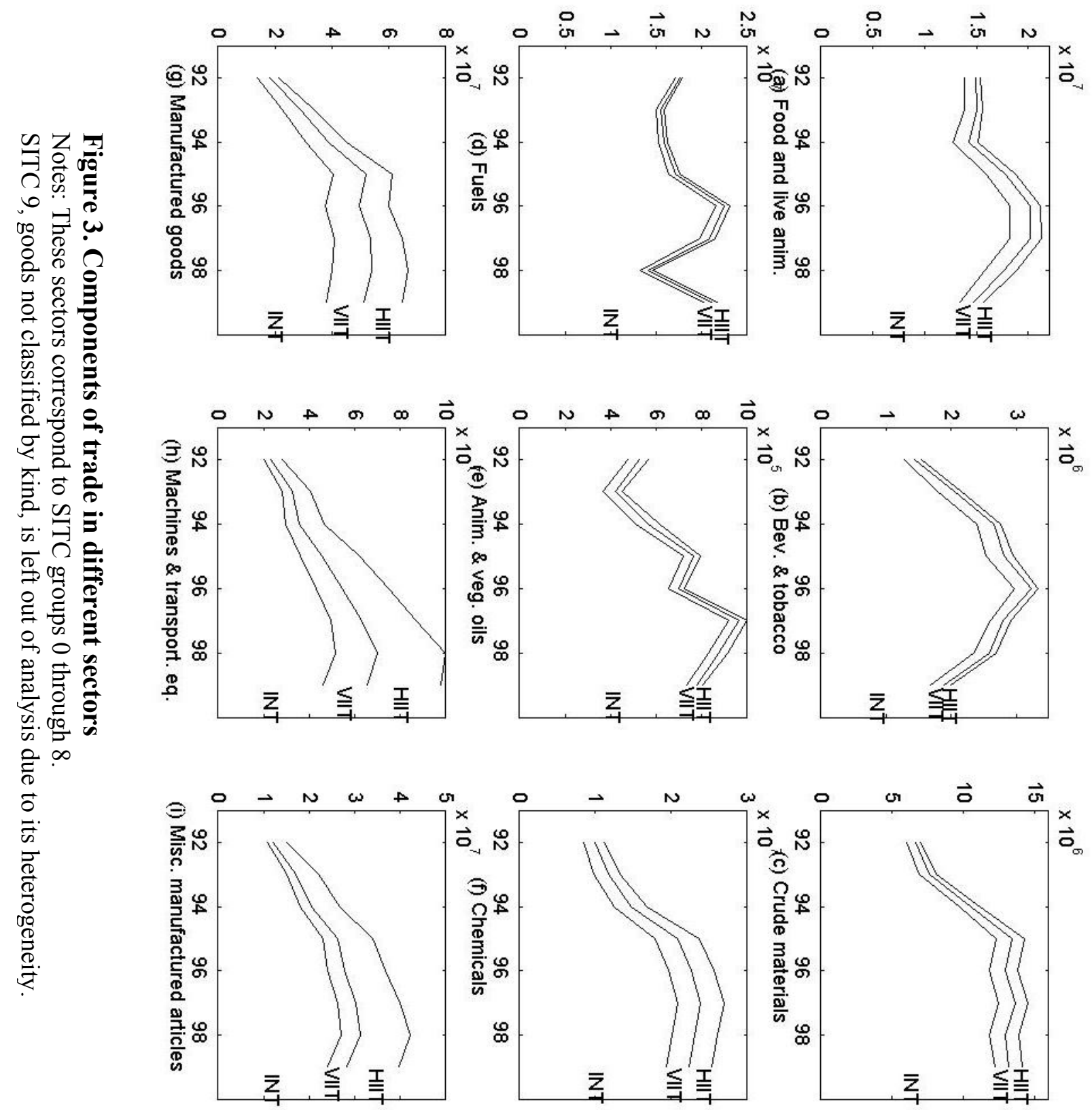


William Davidson Working Paper 566

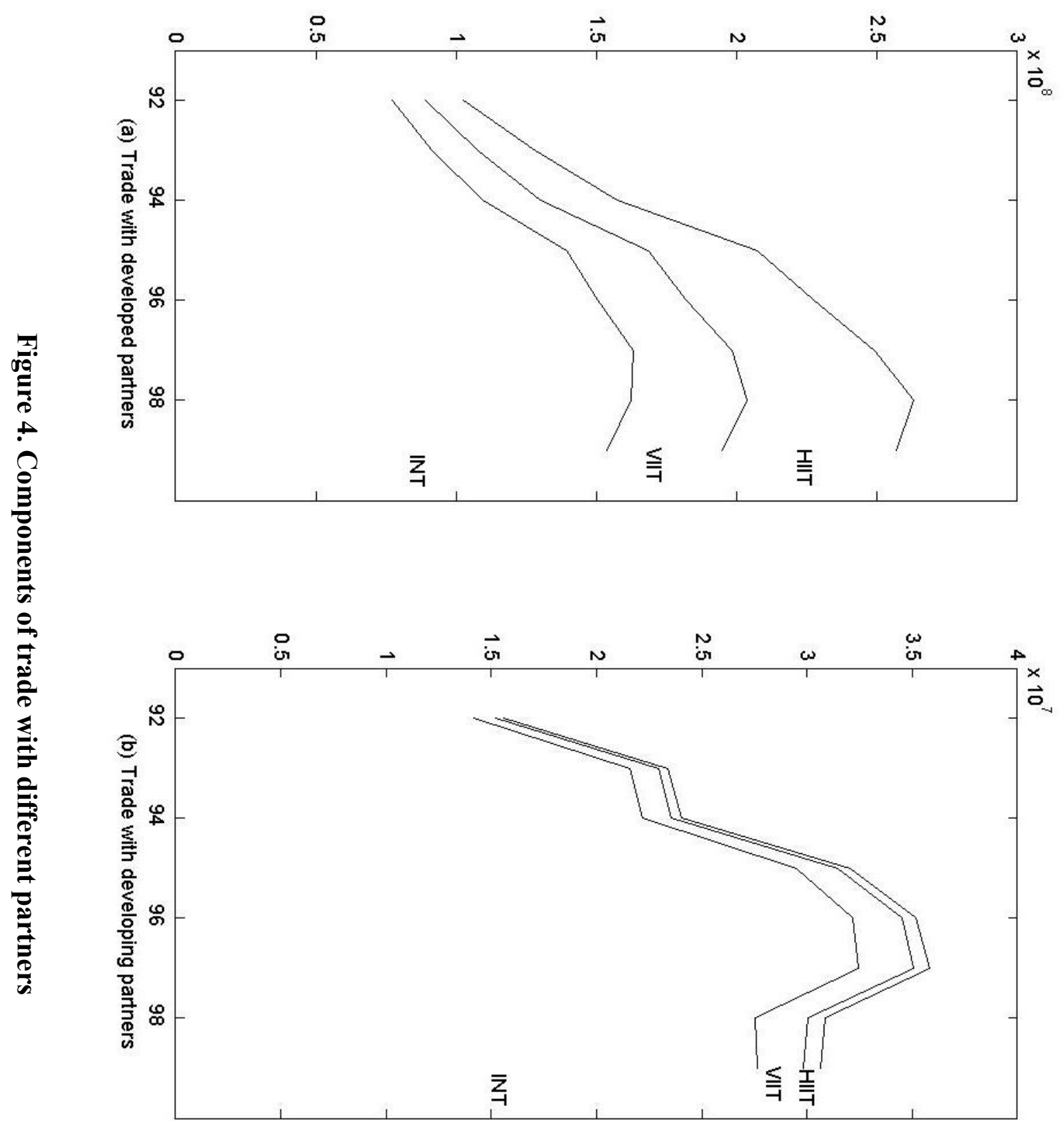




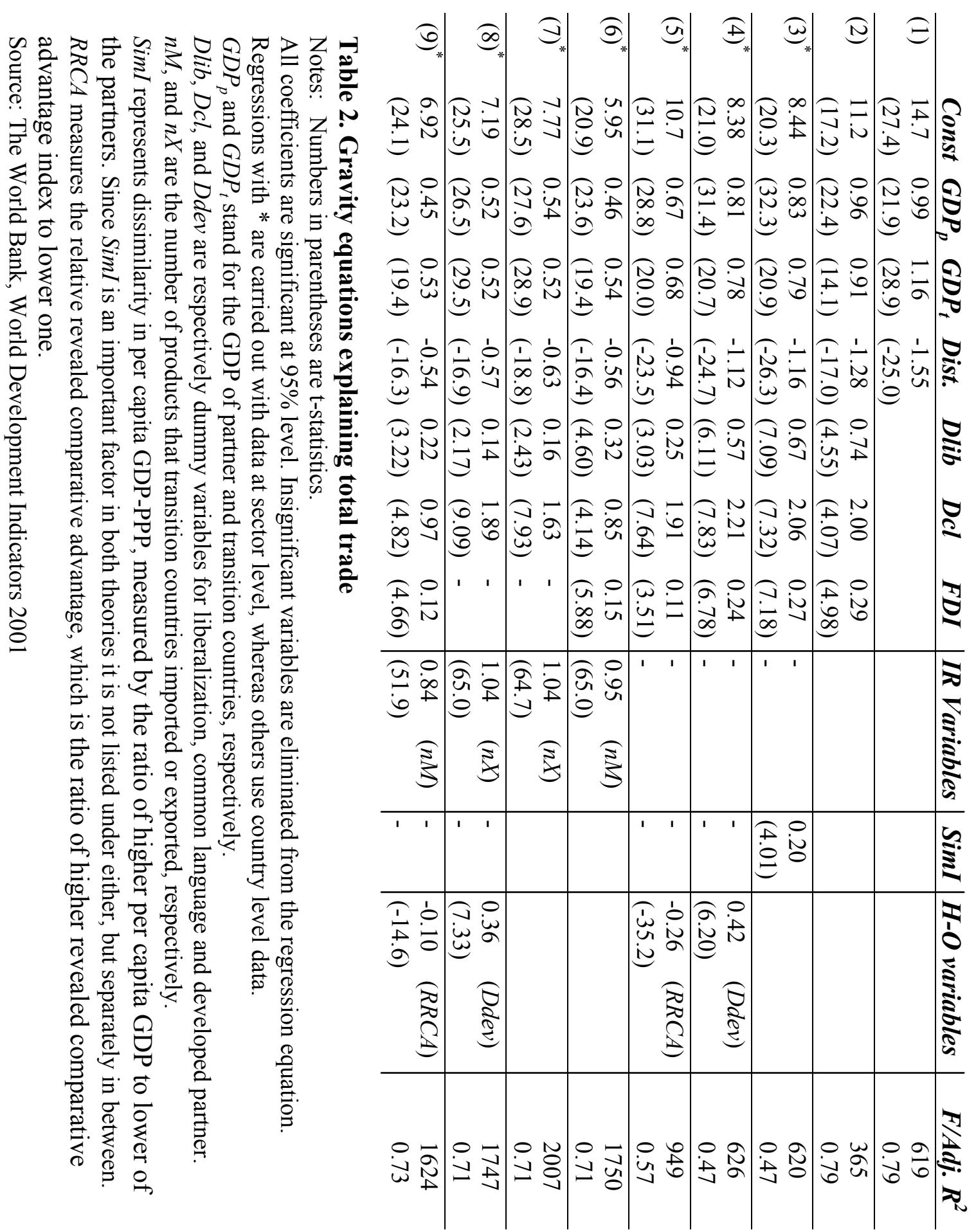




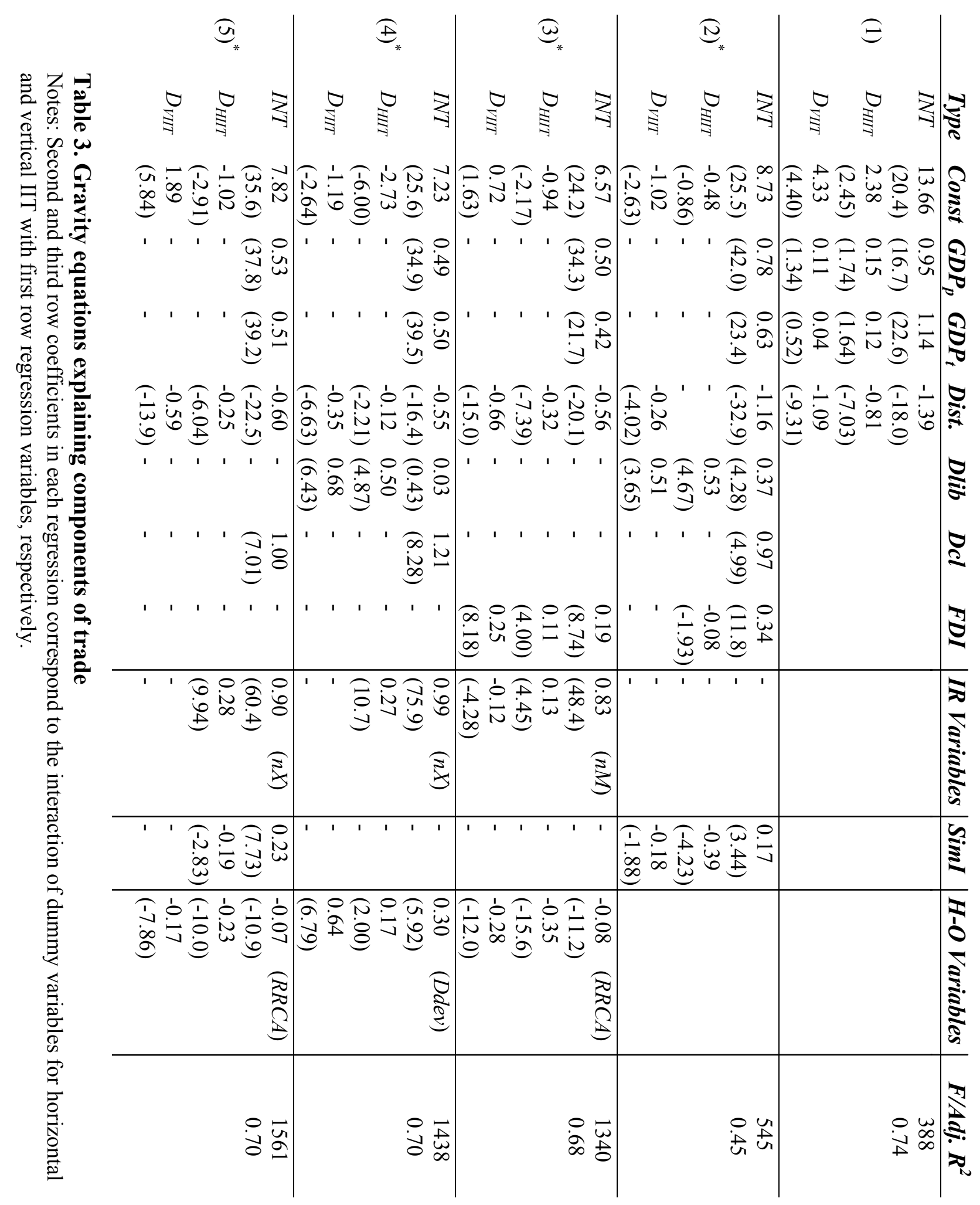




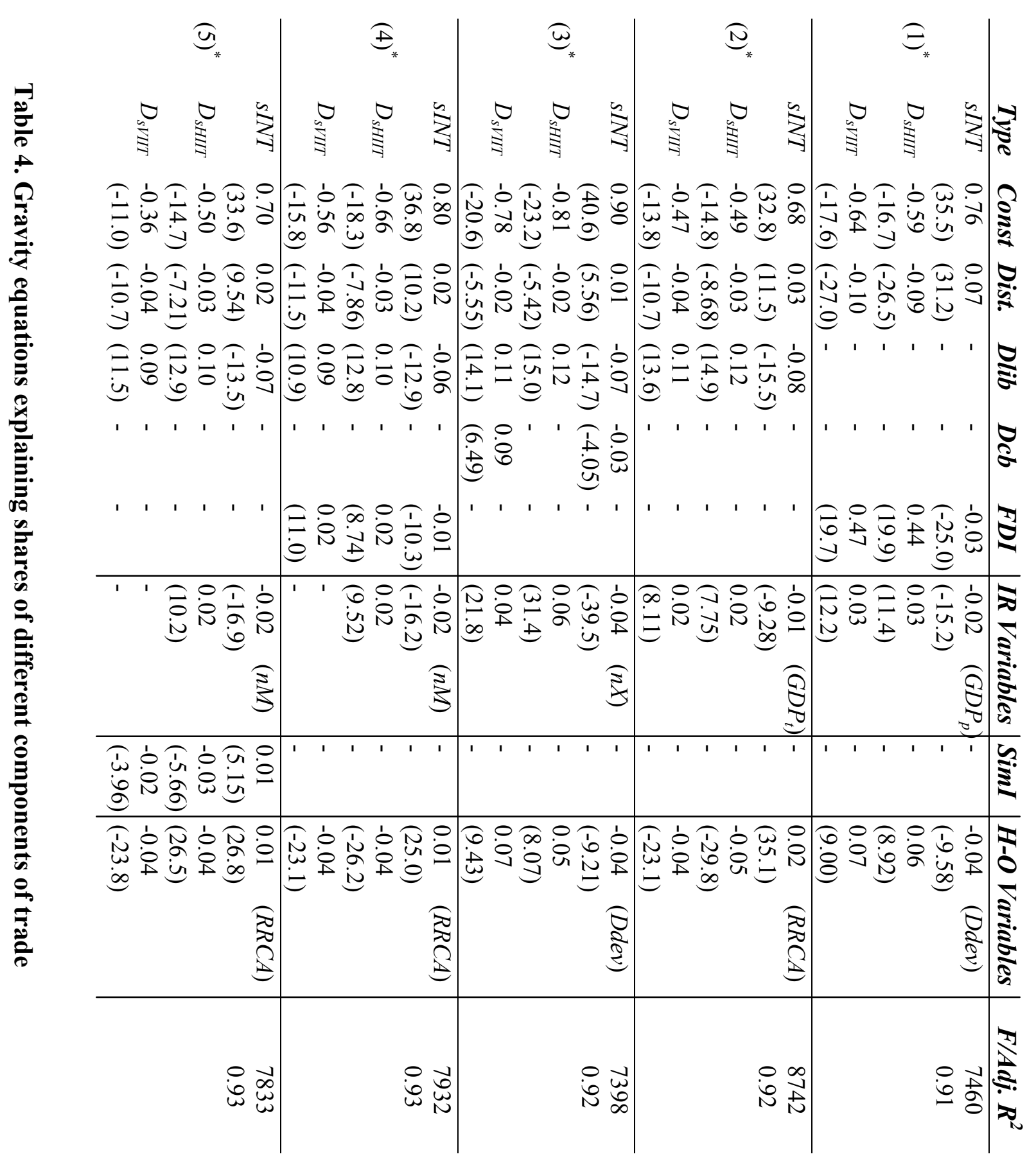




\section{Endnotes:}

${ }^{1}$ In a different framework, Aturupane et al. (1999) analyze the intra-industry trade of eight Central and East European nations with the European Union during 1990-95. This paper extends the analysis to all transition countries to include the former Soviet Union, and their developing and developed trade partners, including the EU.

${ }^{2}$ Although the large volume of IIT is often cited as an element favoring Increasing Returns Trade Theory over H-O Theory, Davis (1995) provides an account of IIT within H-O framework with technical differences.

${ }^{3}$ For example, Durkin and Krygier (2000) find positive relation between income differences and IIT in OLS regressions, and negative relation in fixed-effect regressions is due failure to separate out the vertical IIT.

4 In December 1995, Russia, Belarus, and Kazakhstan formed a customs union, which Kyrgyzstan joined in December 1996.

5 For detailed analysis of Turkish IIT with Central Asian countries, see Gonel (2001).

${ }^{6}$ Analyzing different set of countries, Bhattacharyya (2002) also finds that relatively high levels of IIT in machine and transport equipment sectors, and manufacturing.

${ }^{7}$ Incidentally, analyzing the trade of developing Asian and Latin American countries' trade, Bhattacharyya (2002) finds that similarity in level of development is important for IIT.

${ }^{8}$ The data for distance is obtained from US Census. Its measurement uses the latitude and longitude of the two places, and calculates the direct distance as the crow flies.

${ }^{9}$ Due to high correlation between FDI and number of products transition countries export, FDI is omitted from the model in regression (7).

${ }^{10}$ IIT is also found to decline more significantly with distance in Clark and Stanley (1999). 
William Davidson Working Paper 566

${ }^{11}$ Clark (1993) does not find support for the role of scale economies in explaining IIT.

12 Durkin and Krygier (1998), and Torstensson (1996) find empirical support for the effect of comparative advantage in explaining vertical intra-industry trade as well. 


\section{DAVIDSON INSTITUTE WORKING PAPER SERIES - Most Recent Papers}

The entire Working Paper Series may be downloaded free of charge at: www.wdi.bus.umich.edu

CURRENT AS OF 5/1/03

\begin{tabular}{|c|c|c|}
\hline Publication & Authors & Date \\
\hline $\begin{array}{l}\text { No. 566: Intra-industry Trade of Transition Countries: Trends and } \\
\text { Determinants }\end{array}$ & Yener Kandogan & May 2003 \\
\hline $\begin{array}{l}\text { No. 565: Local Protectionism and Regional Specialization: Evidence } \\
\text { from China's Industries }\end{array}$ & $\begin{array}{l}\text { Chong-En Bai, Yingjuan Du, } \\
\text { Zhigang Tao, Sarah Y. Tong }\end{array}$ & May 2003 \\
\hline No. 564: Corporate Governance and Market Valuation in China & $\begin{array}{l}\text { Chong-En Bai, Qiao Liu, Joe Lu, } \\
\text { Frank M. Song, and Junxi Zhang }\end{array}$ & May 2003 \\
\hline $\begin{array}{l}\text { No. 563: Revenue Sharing and Control Rights in Team Production: } \\
\text { Theories and Evidence From Joint Ventures }\end{array}$ & $\begin{array}{l}\text { Chong-En Bai, Zhigang Tao, and } \\
\text { Changqi Wu }\end{array}$ & May 2003 \\
\hline $\begin{array}{l}\text { No. 562: Financial Dependence, Stock Market Liberalizations and } \\
\text { Growth }\end{array}$ & Nandini Gupta and Kathy Yuan & May 2003 \\
\hline $\begin{array}{l}\text { No. 561: Growth and Regional Inequality in China During the Reform } \\
\text { Era }\end{array}$ & Derek Jones, Cheng Li and Owen & May 2003 \\
\hline $\begin{array}{l}\text { No. 560: Choice of Ownership Structure and Firm Performance: } \\
\text { Evidence from Estonia }\end{array}$ & $\begin{array}{l}\text { Derek Jones, Panu Kalmi, Niels } \\
\text { Mygind }\end{array}$ & May 2003 \\
\hline No. 559: Explaining Postcommunist Economic Performance & Lawrence P. King & May 2003 \\
\hline $\begin{array}{l}\text { No. 558: Tax Structure and the FDI: The Deterrent Effects of } \\
\text { Complexity and Uncertainty }\end{array}$ & $\begin{array}{l}\text { Kelly Edmiston, Shannon Mudd } \\
\text { and Neven Valev }\end{array}$ & Apr. 2003 \\
\hline No. 557: Provincial Protectionism & Konstantin Sonin & Apr. 2003 \\
\hline $\begin{array}{l}\text { No. 556: Nominal and Real Convergence in Estonia: The Balassa- } \\
\text { Samuelson (dis)connection }\end{array}$ & Balázs Égert & Apr. 2003 \\
\hline $\begin{array}{l}\text { No. 555: Banks-Firms Nexus under the Currency Board: Empirical } \\
\text { Evidence from Bulgaria }\end{array}$ & $\begin{array}{l}\text { Nikolay Nenovsky, Evgeni Peev } \\
\text { and Todor Yalamov }\end{array}$ & Apr. 2003 \\
\hline $\begin{array}{l}\text { No. 554: To Steal or Not to Steal: Firm Attributes, Legal Environment, } \\
\text { and Valuation }\end{array}$ & Art Durnev and E. Han Kim & Apr. 2003 \\
\hline No. 553: Corporate Stability and Economic Growth & $\begin{array}{l}\text { Kathy S. He, Randall Morck and } \\
\text { Bernard Yeung }\end{array}$ & Apr. 2003 \\
\hline $\begin{array}{l}\text { No. 552: So Many Rocket Scientists, So Few Marketing Clerks: } \\
\text { Occupational Mobility in Times of Rapid Technological Change }\end{array}$ & $\begin{array}{l}\text { Nauro F. Campos and Aurelijus } \\
\text { Dabušinskas }\end{array}$ & Mar. 2003 \\
\hline $\begin{array}{l}\text { No. 551: Determinants of Interregional Mobility in Russia: Evidence } \\
\text { from Panel Data }\end{array}$ & $\begin{array}{l}\text { Yuri Andrienko and Sergei } \\
\text { Guriev }\end{array}$ & Feb. 2003 \\
\hline $\begin{array}{l}\text { No. 550: Gross Job Flows in Ukraine: Size, Ownership and Trade } \\
\text { Effects }\end{array}$ & $\begin{array}{l}\text { Jozef Konings, Olga Kupets and } \\
\text { Hartmut Lehmann }\end{array}$ & Mar. 2003 \\
\hline $\begin{array}{l}\text { No. 549: Technology Transfer through FDI in Top-10 Transition } \\
\text { Countries: How Important are Direct Effects, Horizontal and Vertical } \\
\text { Spillovers? }\end{array}$ & $\begin{array}{l}\text { Jože P. Damijan, Mark Knell, } \\
\text { Boris Majcen and Matija Rojec }\end{array}$ & Feb. 2003 \\
\hline $\begin{array}{l}\text { No. 548: Does Foreign Direct Investment Increase the Productivity of } \\
\text { Domestic Firms? In Search of Spillovers through Backward Linkages }\end{array}$ & Beata K. Smarzynska & Mar. 2003 \\
\hline $\begin{array}{l}\text { No. 547: Re-employment Probabilities and Wage Offer Function for } \\
\text { Russian Labor Market }\end{array}$ & Natalia V. Smirnova & Feb. 2003 \\
\hline $\begin{array}{l}\text { No. 546: Democratization's Risk Premium: Partisan and Opportunistic } \\
\text { Political Business Cycle Effects on Sovereign Ratings in Developing } \\
\text { Countries }\end{array}$ & $\begin{array}{l}\text { Steven Block, Burkhard N. } \\
\text { Schrage and Paul M. Vaaler }\end{array}$ & Feb. 2003 \\
\hline $\begin{array}{l}\text { No. 545: Structural Reforms and Competitiveness: Will Europe } \\
\text { Overtake America? }\end{array}$ & Jan Svejnar & Feb. 2003 \\
\hline No. 544: Why the Rich May Favor Poor Protection of Property Rights & Konstantin Sonin & Dec. 2002 \\
\hline $\begin{array}{l}\text { No. 543: Reinvested Earnings Bias, The "Five Percent" Rule and the } \\
\text { Interpretation of the Balance of Payments - With an Application to } \\
\text { Transition Economies }\end{array}$ & $\begin{array}{l}\text { Josef C. Brada and Vladimír } \\
\text { Tomšík }\end{array}$ & Feb. 2003 \\
\hline $\begin{array}{l}\text { No. 542: The Impact of Ownership Reform in Chinese Industry, 1995- } \\
2001\end{array}$ & $\begin{array}{l}\text { Gary H. Jefferson, Su Jian, Jiang } \\
\text { Yuan and Yu Xinhua }\end{array}$ & Feb. 2003 \\
\hline $\begin{array}{l}\text { No. 541: Defensive and Strategic Restructuring of Firms during the } \\
\text { Transition to a Market Economy }\end{array}$ & $\begin{array}{l}\text { Domadenik, Janez Prašnikar and } \\
\text { Jan Svejnar }\end{array}$ & Feb. 2003 \\
\hline
\end{tabular}

